Article

\title{
Understanding the Heat Shock Response in the Sea Cucumber Apostichopus japonicus, Using iTRAQ-Based Proteomics
}

\author{
Dongxue $\mathrm{Xu}{ }^{1,2}$, Lina Sun ${ }^{1, *}$, Shilin Liu ${ }^{1}$, Libin Zhang ${ }^{1}$ and Hongsheng Yang ${ }^{1, *}$ \\ 1 Key Laboratory of Marine Ecology and Environmental Sciences, Institute of Oceanology, \\ Chinese Academy of Sciences, Qingdao 266071, China; dongxuexu1989@126.com (D.X.); \\ shlliu72@126.com (S.L.); zhanglibin@qdio.ac.cn (L.Z.) \\ 2 University of Chinese Academy of Sciences, Beijing 100049, China \\ * $\quad$ Correspondence: sunlina713@163.com (L.S.); hshyang@ms.qdio.ac.cn (H.Y.); Tel.: +86-532-8289-8645 (L.S.); \\ +86-532-8289-8610 (H.Y.)
}

Academic Editor: David Sheehan

Received: 26 November 2015; Accepted: 20 January 2016; Published: 4 February 2016

\begin{abstract}
The sea cucumber Apostichopus japonicus is exploited as a commercial species owing to their high nutritive and medicinal value. Recent high summer temperatures have caused high mortality rates in A. japonicus. In this study, we applied the isobaric tag for relative and absolute quantitation (iTRAQ) technique to investigate the global protein expression profile under an acute short-term $(48 \mathrm{~h})$ heat stress. In total, 3432 proteins were identified, and 127 proteins showed significant heat stress responses, with 61 upregulated proteins and 66 downregulated proteins. Our results suggest that heat stress influenced the expression of proteins involved in various biological processes, such as tissue protection and detoxification, lipid and amino acid metabolism, energy production and usage, transcription and translation, cell apoptosis, and cell proliferation. These findings provide a better understanding about the response and thermo-tolerance mechanisms of $A$. japonicus under heat stress.
\end{abstract}

Keywords: Apostichopus japonicus; heat stress; iTRAQ; proteomics analysis

\section{Introduction}

The effects of global warming include rising mean annual temperatures and dramatic increase in the frequency and amplitude of severe temperature events [1]. These fluctuations constitute a major threat to aquatic organisms, as they are naturally exposed to changing water temperature. The sea cucumber Apostichopus japonicus, is an echinoderm distributed along the coast of northern China, southeastern Russia, Japan, the Republic of Korea, and the Democratic People's Republic of Korea [2]. A. japonicus has been exploited as a commercial species owing to their high nutritive and medicinal value. Temperature is the pivotal environmental factor affecting the growth and physiology of $A$. japonicus [3]. Recent high summer temperatures have caused high mortality rates in cultured A. japonicus. Therefore, a better understanding of the mechanisms involved in the A. japonicus heat shock response would be significant and would lay the theoretical foundation for breeding traits for thermo-tolerance. Though specific heat response genes, such as genes from the heat shock protein (HSP) family, have been characterized, a lack of transcriptome and proteome data severely hampers revealing global gene changes and the key pathways that are active in heat stressed A. japonicus [4-6].

Proteomic approaches have been used to identify stress-responsive genes and proteins regulated by high temperatures. Two-dimensional electrophoresis (2DE) is the most frequently utilized approach for a proteomic analysis. However, not all proteins are amenable to gels, and proteins in low abundance 
are hard to be characterized in 2DE approach [7]. Besides, the quantification accuracy and ability of 2DE to identify proteins may be compromised by co-migration or partial co-migration of proteins [8]. A new technique called iTRAQ (isobaric tag for relative and absolute quantitation) has become popular in proteomic analysis in recent years, which provides more reliable quantitative measurements and comparisons among samples [9]. Additionally, the iTRAQ approach has largely improved proteomic analyses throughput and has been used in pathway studies.

In the current study, we applied the iTRAQ technique to assess the proteomic changes in A. japonicus intestinal tissues after heat shock. Our results suggest that heat stress influenced the expression of proteins involved in diverse biological processes, such as tissue protection and detoxification, lipid and amino acid metabolism, energy production and usage, transcription and translation, cell apoptosis, and cell proliferation. These findings provide a better understanding of the response and thermo-tolerance mechanisms in A. japonicus under heat stress.

\section{Results}

\subsection{Overview of the Proteomics Data}

The proteomics data have been deposited to the ProteomeXchange via the PRIDE (Database ID: PXD002660) [10]. Totally 272,754 spectra were obtained, of which 38,588 unique spectra were detected (Table 1). A total 3423 proteins were identified at a global false discovery rate of $1 \%$ (Table S1). The global expression changes of these proteins under heat stress were shown in Figure 1. Finally, 127 proteins showed significant heat stress responses, with 61 upregulated proteins (Table 2) and 66 downregulated proteins (Table 3).

Table 1. Overview of the proteomics sequencing results.

\begin{tabular}{cc}
\hline Group Name & Number \\
\hline Total spectra & 272,754 \\
Spectra & 41,330 \\
Unique spectra & 38,588 \\
Peptide & 10,908 \\
Unique peptide & 10,486 \\
Protein & 3432 \\
Upregulated protein & 61 \\
Downregulated protein & 66 \\
\hline
\end{tabular}

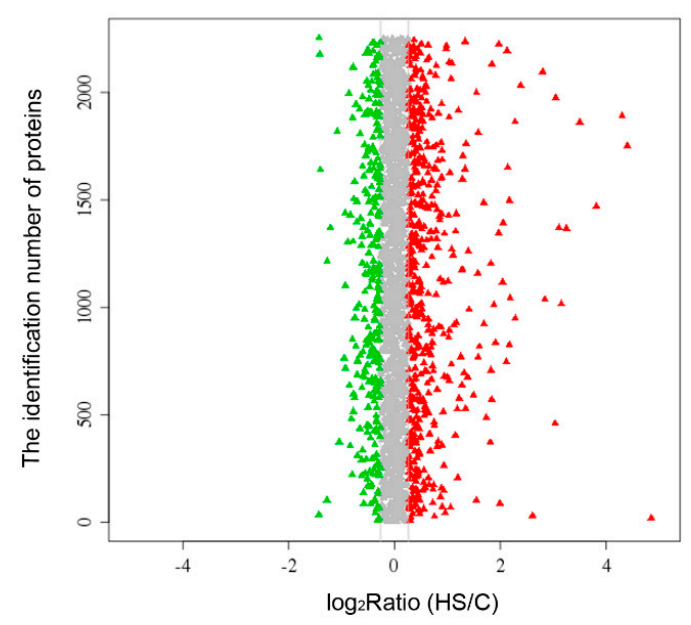

Figure 1. The change level of global proteins in the intestine in the heat shock group (HS) compared with the control group (C). Only the proteins with $\log _{2}$ Ratio (HS $/ C$ ) $>0.26$ or $<-0.26$ were colored (fold changes $>1.20$ as red and $<0.83$ as green). 
Table 2. Sixty-one upregulated proteins under heat stress in the intestine of the sea cumber A. japonicas.

\begin{tabular}{|c|c|c|c|}
\hline \multirow{2}{*}{ Accession Number } & \multirow{2}{*}{ Protein Description } & \multicolumn{2}{|c|}{ HS vs. Control } \\
\hline & & Mean & SD \\
\hline \multicolumn{4}{|c|}{ HSPs and Related Proteins } \\
\hline Unigene28963 & heat shock protein 90 & 6.10 & 4.25 \\
\hline CL6821.Contig1 & heat shock protein 70 & 1.56 & 0.62 \\
\hline CL5625.Contig2 & heat shock protein 110 & 1.41 & 0.22 \\
\hline Unigene15437 & heat shock protein 10 & 1.20 & 0.01 \\
\hline CL12434.Contig1 & heat repeat-containing protein $7 \mathrm{~A}$ & 1.36 & 0.19 \\
\hline \multicolumn{4}{|c|}{ Detoxification and Tissue Protection } \\
\hline Unigene61290 & glutathione $S$-transferase & 1.36 & 0.07 \\
\hline CL6008.Contig2 & glutathione $S$-transferase $\alpha$-4-like, partial & 2.23 & 0.72 \\
\hline Unigene25399 & sigma class glutathione $S$-transferase 2 & 1.29 & 0.26 \\
\hline CL7884.Contig2 & phospholipid hydroperoxide glutathione peroxidase & 1.45 & 0.16 \\
\hline Unigene29285 & prostaglandin D2 synthase, hematopoietic-like & 1.53 & 0.35 \\
\hline Unigene25766 & cytochrome P450 4V2-like & 2.43 & 1.45 \\
\hline \multicolumn{4}{|c|}{ Cell Apoptosis and Proliferation } \\
\hline Unigene29013 & apoptosis-inducing factor 1 , mitochondrial-like, partial & 1.28 & 0.20 \\
\hline CL4411.Contig2 & prohibitin-like & 1.19 & 0.12 \\
\hline CL2387.Contig1 & autocrine proliferation repressor protein A-like & 3.57 & 3.08 \\
\hline Unigene33274 & $\begin{array}{c}\text { suppression of tumorigenicity } 13 \text { (colon carcinoma) (Hsp70 } \\
\text { interacting protein) }\end{array}$ & 1.27 & 0.09 \\
\hline CL10790.Contig2 & erlin-1 & 1.29 & 0.04 \\
\hline Unigene35102 & mesoderm-specific transcript protein (MEST) & 2.61 & 2.19 \\
\hline \multicolumn{4}{|c|}{ Lipid Transport and Metabolism } \\
\hline Unigene64084 & long-chain specific acyl-CoA dehydrogenase & 1.41 & 0.24 \\
\hline Unigene20467 & $\begin{array}{l}\text { long-chain specific acyl-CoA dehydrogenase, } \\
\text { mitochondrial-like }\end{array}$ & 2.22 & 0.72 \\
\hline Unigene22338 & $\begin{array}{l}\text { short chain dehydrogenase/reductase family } 16 \mathrm{C} \text {, member } \\
\text { 5-like }\end{array}$ & 1.74 & 0.58 \\
\hline Unigene4389 & $17-\beta$-hydroxysteroid dehydrogenase type 4 & 1.94 & 1.11 \\
\hline Unigene5795 & $11-\beta$-hydroxysteroid dehydrogenase & 2.54 & 1.24 \\
\hline Unigene6420 & enoyl-CoA Hydratase family member-like & 1.62 & 0.33 \\
\hline CL12084.Contig1 & enoyl-CoA hydratase, mitochondrial-like & 1.30 & 0.16 \\
\hline CL759.Contig2 & hydroxyacyl-Coenzyme A dehydrogenase & 1.34 & 0.31 \\
\hline Unigene19362 & epidermal retinol dehydrogenase 2-like & 1.97 & 0.83 \\
\hline Unigene15259 & carnitine $O$-palmitoyltransferase 2 , mitochondrial-like & 1.21 & 0.06 \\
\hline Unigene11008 & non-specific lipid-transfer protein-like & 2.99 & 1.98 \\
\hline CL4289.Contig1 & nuclear progesterone receptor & 1.46 & 0.23 \\
\hline CL6901.Contig2 & $2^{\prime}$-deoxynucleoside $5^{\prime}$-phosphate $N$-hydrolase 1 & 1.43 & 0.27 \\
\hline CL8136.Contig1 & acyl-CoA-binding protein like, ACBP2 & 2.33 & 1.46 \\
\hline Unigene18754 & oxysterol-binding protein-related protein 9 & 1.20 & 0.18 \\
\hline \multicolumn{4}{|c|}{ Carbohydrate Transport and Metabolism } \\
\hline Unigene2131 & lactase & 1.48 & 0.10 \\
\hline \multicolumn{4}{|c|}{ Amino Acid Transport and Metabolism } \\
\hline CL4095.Contig2 & sphingosine-1-phosphate lyase 1 & 1.33 & 0.27 \\
\hline Unigene23212 & branched-chain-amino-acid aminotransferase-like protein 1 & 1.39 & 0.32 \\
\hline \multicolumn{4}{|c|}{ Energy Production and Conversion } \\
\hline CL10773.Contig1 & isocitrate dehydrogenase & 1.68 & 0.19 \\
\hline Unigene18857 & electron transfer flavoprotein subunit $\alpha$, mitochondrial-like & 1.27 & 0.25 \\
\hline CL6007.Contig1 & aldehyde dehydrogenase, dimeric NADP-preferring isoform & 1.37 & 0.22 \\
\hline Unigene22955 & $\alpha$-methylacyl-CoA racemase-like & 1.65 & 0.66 \\
\hline Unigene175 & D-glucosyl- $N$-acylsphingosine glucohydrolase & 1.85 & 0.31 \\
\hline Unigene22578 & $\alpha$-galactosidase & 1.91 & 1.26 \\
\hline Unigene29260 & ATPase family AAA domain-containing protein 1 & 1.35 & 0.05 \\
\hline CL5389.Contig1 & ATPase inhibitor, mitochondrial-like & 1.31 & 0.21 \\
\hline
\end{tabular}


Table 2. Cont.

\begin{tabular}{|c|c|c|c|}
\hline \multirow{2}{*}{$\begin{array}{c}\text { Accession } \\
\text { Number }\end{array}$} & \multirow{2}{*}{ Protein Description } & \multicolumn{2}{|c|}{ HS vs. Control } \\
\hline & & Mean & SD \\
\hline \multicolumn{4}{|c|}{ Protein Synthesis } \\
\hline CL9215.Contig1 & aspartyl-tRNA synthetase & 1.17 & 0.11 \\
\hline CL7807.Contig3 & RNA-binding motif protein, $\mathrm{X}$ chromosome & 1.25 & 0.19 \\
\hline Unigene 8195 & elongation factor Tu, mitochondrial-like & 1.34 & 0.20 \\
\hline \multicolumn{4}{|c|}{ Others/Uncharacterized } \\
\hline Unigene49395 & toposome & 1.83 & 0.81 \\
\hline Unigene28479 & natterin-3-like & 2.63 & 1.01 \\
\hline CL6732.Contig2 & calpain-5 isoform 2 & 1.38 & 0.37 \\
\hline Unigene22143 & phospholipase $\mathrm{C}$ delta isoform & 2.55 & 0.58 \\
\hline CL1115.Contig1 & endophilin-B1-like isoform 1 & 1.32 & 0.19 \\
\hline Unigene322 & myosin VIb-like & 1.32 & 0.24 \\
\hline CL7807.Contig3 & atlastin-2 & 1.33 & 0.23 \\
\hline CL9074.Contig2 & cysteine rich protein 1 & 1.59 & 0.18 \\
\hline Unigene11767 & suppressor of G2 allele of SKP1 homolog & 1.53 & 0.14 \\
\hline CL8638.Contig1 & development-specific protein LVN1.2 & 1.71 & 0.62 \\
\hline Unigene22386 & uncharacterized & 1.39 & 0.35 \\
\hline Unigene1947 & uncharacterized & 3.76 & 1.54 \\
\hline Unigene5634 & uncharacterized & 1.66 & 0.38 \\
\hline Unigene16247 & uncharacterized & 2.11 & 1.58 \\
\hline Unigene62712 & uncharacterized & 11.32 & 9.13 \\
\hline
\end{tabular}

Table 3. Sixty-six downregulated proteins under heat stress in the intestine of the sea cucumber A. japonicas.

\begin{tabular}{|c|c|c|c|}
\hline \multirow{2}{*}{ Accession Number } & \multirow{2}{*}{ Protein Description } & \multicolumn{2}{|c|}{ HS vs. Control } \\
\hline & & Mean & SD \\
\hline \multicolumn{4}{|c|}{ Cytoskeletal Proteins } \\
\hline Unigene32477 & twitchin-like & 0.67 & 0.21 \\
\hline Unigene32260 & laminin subunit $\alpha$-like & 0.68 & 0.13 \\
\hline CL221.Contig4 & $\alpha$-actinin-like & 0.76 & 0.10 \\
\hline Unigene3881 & galectin-9-like & 0.56 & 0.29 \\
\hline Unigene27394 & fibrillin-1-like & 0.52 & 0.17 \\
\hline CL5005.Contig4 & cohesin subunit SA-1-like & 0.69 & 0.25 \\
\hline Unigene9716 & titin isoform 3 & 0.72 & 0.17 \\
\hline CL3832.Contig7 & filamin-C isoform 1 & 0.83 & 0.01 \\
\hline Unigene30625 & muscle M-line assembly protein unc-89-like & 0.71 & 0.10 \\
\hline \multicolumn{4}{|c|}{ Transcription and Translation } \\
\hline Unigene29879 & $60 S$ ribosomal protein L8-like & 0.79 & 0.11 \\
\hline Unigene26472 & $60 \mathrm{~S}$ ribosomal protein L6, partial & 0.82 & 0.15 \\
\hline Unigene8941 & ribosomal protein L4, partial & 0.82 & 0.09 \\
\hline CL1672.Contig2 & $60 \mathrm{~S}$ ribosomal protein L10-like & 0.73 & 0.14 \\
\hline CL4437.Contig3 & splicing factor, proline- and glutamine-rich & 0.62 & 0.05 \\
\hline CL5572.Contig1 & THO complex subunit 4 & 0.64 & 0.25 \\
\hline Unigene22920 & small nuclear ribonucleoprotein-associated proteins $\mathrm{B}$ and $\mathrm{B}^{\prime}$ & 0.81 & 0.12 \\
\hline Unigene15894 & malectin & 0.75 & 0.08 \\
\hline \multicolumn{4}{|c|}{ DNA Replication and Repair } \\
\hline CL1035.Contig9 & histone H3.3 & 0.66 & 0.29 \\
\hline Unigene5846 & histone $\mathrm{H} 1-\beta$, late embryonic & 0.61 & 0.05 \\
\hline CL5357.Contig1 & legumain-like & 0.67 & 0.20 \\
\hline CL64.Contig2 & poly(ADP-ribose) polymerase pme-5-like & 0.77 & 0.08 \\
\hline Unigene9968 & ATP-binding cassette, sub-family C, member 9-like & 0.69 & 0.01 \\
\hline
\end{tabular}


Table 3. Cont.

\begin{tabular}{|c|c|c|c|}
\hline \multirow{2}{*}{ Accession Number } & \multirow{2}{*}{ Protein Description } & \multicolumn{2}{|c|}{ HS vs. Control } \\
\hline & & Mean & SD \\
\hline \multicolumn{4}{|c|}{ Amino Acid Transport and Mechanism } \\
\hline CL4631.Contig1 & choline dehydrogenase, mitochondrial-like & 0.65 & 0.17 \\
\hline Unigene11760 & branched-chain-amino-acid aminotransferase, cytosolic & 0.71 & 0.08 \\
\hline CL3226.Contig1 & tyrosine aminotransferase-like & 0.66 & 0.28 \\
\hline Unigene25781 & aminopeptidase $N$-like & 0.72 & 0.13 \\
\hline CL12737.Contig1 & glutamyl aminopeptidase & 0.79 & 0.16 \\
\hline CL2682.Contig1 & cytosolic serine hydroxymethyltransferase & 0.73 & 0.08 \\
\hline CL9582.Contig2 & xaa-Pro aminopeptidase 1 isoform X3 & 0.76 & 0.09 \\
\hline Unigene36365 & betaine homocysteine $S$-methyltransferase 1 & 0.58 & 0.22 \\
\hline Unigene3911 & betaine homocysteine $S$-methyltransferase 1-like & 0.38 & 0.10 \\
\hline \multicolumn{4}{|c|}{ Lipid Transport and Mechanism } \\
\hline Unigene27722 & peroxisomal bifunctional enzyme-like & 0.78 & 0.14 \\
\hline Unigene10407 & peroxisomal bifunctional enzyme & 0.81 & 0.07 \\
\hline CL8765.Contig2 & dihydropteridine reductase & 0.74 & 0.09 \\
\hline CL1598.Contig1 & $\gamma$-butyrobetaine dioxygenase-like & 0.60 & 0.22 \\
\hline \multicolumn{4}{|c|}{ Carbohydrate Transport and Metabolism } \\
\hline Unigene27857 & $\alpha$-mannosidase 2C1-like & 0.47 & 0.24 \\
\hline Unigene18547 & pyruvate carboxylase, mitochondrial & 0.73 & 0.15 \\
\hline \multicolumn{4}{|c|}{ Hormonal and Nerve Regulation } \\
\hline Unigene25501 & thyroid hormone-induced protein B-like & 0.41 & 0.28 \\
\hline CL9528.Contig2 & proactivator polypeptide & 0.72 & 0.23 \\
\hline Unigene19435 & angiotensin-converting enzyme & 0.38 & 0.18 \\
\hline CL7652.Contig1 & potassium channel tetramerization domain containing 6-like & 0.37 & 0.29 \\
\hline CL5238.Contig2 & glutamate receptor 1-like & 0.68 & 0.08 \\
\hline \multicolumn{4}{|c|}{ Others/Uncharacterized } \\
\hline Unigene1888b1 & sterigmatocystin biosynthesis dehydrogenase stcV & 0.65 & 0.26 \\
\hline CL5732.Contig1 & $N$-acetylated- $\alpha$-linked acidic dipeptidase 2 -like isoform 1 & 0.58 & 0.11 \\
\hline CL9717.Contig2 & peroxiredoxin-4-like & 0.53 & 0.07 \\
\hline Unigene25753 & homogentisate 1,2-dioxygenase & 0.56 & 0.32 \\
\hline CL2303.Contig2 & cathepsin L & 0.70 & 0.26 \\
\hline Unigene8231 & $\alpha$-parvin-like & 0.77 & 0.11 \\
\hline CL7154.Contig1 & sorcin & 0.82 & 0.10 \\
\hline Unigene32921 & thiopurine $S$-methyltransferase isoform $\mathrm{X} 2$ & 0.75 & 0.07 \\
\hline CL2660.Contig13 & $\begin{array}{c}\text { phosphatidylinositol-binding clathrin assembly protein unc-11-like } \\
\text { isoform } 6\end{array}$ & 0.80 & 0.09 \\
\hline Unigene15838 & cytochrome P450 2N2 & 0.70 & 0.10 \\
\hline CL2540.Contig2 & cytochrome P450 2U1-like & 0.58 & 0.05 \\
\hline Unigene23131 & oocyst wall protein 4 precursor & 0.58 & 0.10 \\
\hline CL4607.Contig1 & uterine-ovary specific- 44 protein & 0.79 & 0.14 \\
\hline CL10965.Contig2 & MAM and LDL-receptor class A domain-containing protein 2-like & 0.73 & 0.13 \\
\hline Unigene11852 & uncharacterized & 0.74 & 0.17 \\
\hline Unigene8201 & uncharacterized & 0.62 & 0.21 \\
\hline Unigene63234 & uncharacterized & 0.55 & 0.34 \\
\hline Unigene11761 & uncharacterized & 0.77 & 0.08 \\
\hline CL11132.Contig3 & uncharacterized & 0.59 & 0.23 \\
\hline Unigene23211 & uncharacterized & 0.77 & 0.20 \\
\hline CL12015.Contig1 & uncharacterized & 0.58 & 0.19 \\
\hline CL709.Contig5 & uncharacterized & 0.37 & 0.27 \\
\hline Unigene8605 & uncharacterized & 0.78 & 0.03 \\
\hline CL3869.Contig4 & uncharacterized & 0.58 & 0.12 \\
\hline
\end{tabular}

\subsection{Gene Ontology (GO) and Kyoto Encyclopedia of Genes and Genomes (KEGG) Pathway Enrichment Analyses}

A GO analysis was performed to evaluate the functions of the differentially expressed proteins. Totals of 15, 12, and 59 categories were enriched in cellular component (CC), molecular function (MF) and biological process (BP) categories, respectively (Table S2). Fiber components (sarcomere, myofibril, 
contractile fiber part, and contractile fiber), binding functions (identical protein binding, receptor binding, coenzyme binding, and flavin adenine dinucleotide binding, and actin binding) and response processes (response to organic substance, response to hormone stimulus, response to endogenous stimulus, and response to lipid) were of the top 10 enriched GO-terms by cluster frequency in CC, MF and BP, respectively (Figure 2).

A KEGG pathway enrichment analysis revealed seven upregulated pathways, of which xenobiotics metabolism and fatty acid related metabolisms were included (Table 4). Systemic lupus erythematosus and the renin-angiotensin system were identified as downregulated pathways.

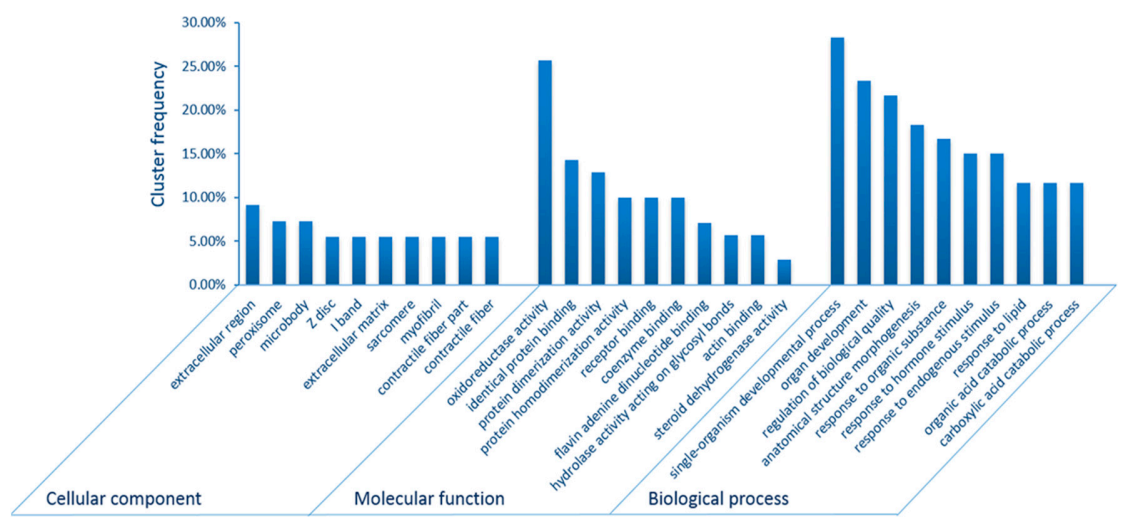

Figure 2. Enriched Gene Ontology (GO) analysis of differentially expressed proteins in the intestine under heat stress. The top 10 enriched GO-terms by cluster frequency in "Cellular component", "Molecular function" and "Biological process" were shown, respectively.

Table 4. Enriched pathways of different expressed proteins (heat stress (HS) vs. Control).

\begin{tabular}{|c|c|c|c|c|}
\hline Pathway ID & Pathway Term & $\begin{array}{l}\text { All Proteins with Pathway } \\
\text { Annotation (2664) }\end{array}$ & $\begin{array}{c}\text { Differential Proteins } \\
\text { with Pathway } \\
\text { Annotation (100) }\end{array}$ & $p$-Value \\
\hline \multicolumn{5}{|c|}{ Upregulated Pathways } \\
\hline ko00480 & Glutathione metabolism & $30(1.13 \%)$ & $6(6 \%)$ & $1.37 \times 10^{-3}$ \\
\hline ko00980 & $\begin{array}{l}\text { Metabolism of xenobiotics by } \\
\text { cytochrome P } 450\end{array}$ & $46(1.73 \%)$ & $7(7 \%)$ & $1.51 \times 10^{-3}$ \\
\hline ko00071 & Fatty acid metabolism & $60(2.25 \%)$ & $8(8 \%)$ & $2.31 \times 10^{-3}$ \\
\hline ko03320 & $\begin{array}{l}\text { Peroxisome proliferator-activated } \\
\text { receptors (PPAR) signaling pathway }\end{array}$ & $64(2.4 \%)$ & $8(8 \%)$ & $4.35 \times 10^{-3}$ \\
\hline ko00120 & Primary bile acid biosynthesis & $56(2.1 \%)$ & $7(7 \%)$ & $8.82 \times 10^{-3}$ \\
\hline ko00982 & Drug metabolism-cytochrome P450 & $51(1.91 \%)$ & $6(6 \%)$ & $1.10 \times 10^{-2}$ \\
\hline ko05215 & Prostate cancer & $37(1.39 \%)$ & $5(5 \%)$ & $1.13 \times 10^{-2}$ \\
\hline \multicolumn{5}{|c|}{ Downregulated Pathways } \\
\hline ko05322 & Systemic lupus erythematosus & $23(0.86 \%)$ & $4(4 \%)$ & $9.55 \times 10^{-3}$ \\
\hline ko04614 & Renin-angiotensin system & $51(1.91 \%)$ & $6(6 \%)$ & $1.10 \times 10^{-2}$ \\
\hline
\end{tabular}

\section{Discussion}

The sea cucumber $A$. japonicus in the northern China experienced the highest temperature between 26 and $30{ }^{\circ} \mathrm{C}$ in the field [11]. Besides, A. japonicus enters a state of aestivation when the ambient temperature is maintained at $26^{\circ} \mathrm{C}$ [3]. Previous reports showed that catalase (CAT) and superoxide dimutase (SOD) activities and HSPs levels varied significantly at $26^{\circ} \mathrm{C}$, indicating that this temperature is beyond the normal temperature limit for A. japonicus [3-5]. Therefore, we investigate the global protein expression profile under $26{ }^{\circ} \mathrm{C}$ heat stress.

\subsection{Tissue Protection and Detoxification}

HSP families play crucial roles protecting organisms against stress by re-establishing normal protein conformation and cellular homeostasis [12]. In our study, heat shock protein 90 (HSP90), 
HSP70, HSP100, and HSP10 were upregulated 6.10-, 1.56-, 1.41-, and 1.20-fold, respectively (Table 2). The protein family HSP90 helps in the processes of protein folding, degradation and transport, and is involved in cell-signal and cell-cycle control $[13,14]$. Our previous A. japonicus study showed that HSP90 also responds to HS at the mRNA level [5]. HSP70 helps prevent protein aggregation, assists in re-folding of abnormal proteins, and is essential for protein import and translocation processes $[15,16]$. HSP70 expression increased under heat stress in this study, which agreed with our previous western blot research of HSP70 [17]. HSP100 expression was also upregulated under heat stress. It is now clear that HSP100 plays a major role in thermo-tolerance, particularly in plants [18]. Recent HSP100 studies have focused on its cooperation with HSP70 during protein disaggregation [19]. HSP10 participates in various processes with HSP60, including the stress response and tumorigenesis [20,21]. In our study, HSP10 was more abundantly expressed under heat stress, which also agreed with our previous HSP10 mRNA study [4]. Taken together, our proteomics data show that four HSPs responded significantly to heat stress, indicating that these HSPs played crucial roles in alleviating heat stress in the sea cucumber $A$. japonicus.

Glutathione (GSH) is involved in many biological processes either as a co-factor of enzymatic reactions or as the major thiol-disulfide redox buffer [22]. Furthermore, GSH and GSH-associated metabolism provide important defense from many forms of stress [23]. In our study, phospholipid hydroperoxide peroxidase (GPx4) and three glutathione transferases (GSTs) were upregulated after heat stress in A. japonicus (Table 2). GPx4, a 20-22 kDa monomer, reduces hydroperoxides of complex lipids by transferring GSH to glutathione disulfide [22]. This process is crucial for scavenging or reducing excess quantities of reactive oxygen species (ROS), thereby maintaining cell redox homeostasis [23]. GSTs are essential enzymes in GSH metabolism, as GSH forms conjugates with a variety of electrophilic compounds, including various xenobiotic compounds, through the actions of GSTs [24]. The GSH conjugates are then exported out of the cell, which is an important component of detoxification [23]. Therefore, upregulation of GSH metabolic enzymes under heat stress is widely regarded as an essential way that cells protect against toxic damage $[22,25,26]$.

\subsection{Lipid, Amino Acid and Carbohydrate Metabolism}

Fifteen proteins involved in lipid transport and mechanisms were upregulated under heat stress in A. japonicus, such as long-chain specific acyl-CoA dehydrogenases (ACADs) and enoyl-CoA hydratases (ECHs). ACADs are a class of enzymes that function to catalyze the initial step of fatty acid $\beta$-oxidation in the mitochondria [27]. Long-chain specific ACADs catalyze the breaking of long chain fatty acids into acetyl-CoA molecules. Two long-chain specific ACADs were highly expressed under heat stress in A. japonicus, reflecting the increasing demand for fatty acid metabolism. ECHs catalyze the second step of $\beta$-oxidation to breakdown fatty acids to produce acetyl-CoA and energy in the form of NADH [28]. These enzymes are highly efficient, allowing cells to metabolize fatty acids into energy very quickly. In our study, $17-\beta-E C H$ type 4 and $11-\beta-E C H$ were upregulated in the intestinal tissues of $A$. japonicus exposed to heat stress, suggesting a shift to lipid metabolism during energy production. These findings correlate well with previous reports suggesting that upregulation of fatty acid metabolism is an important energy budget strategy in a disadvantageous environment [26,29-31].

Nine proteins with roles in amino acid metabolism were less abundant in the HS group (Table 3). Notably, two types of betaine homocysteine S-methyltransferase (BHMT), BHMT1 and BHMT1-like, were downregulated 0.58- and 0.38-fold, respectively. BHMTs use betaine to catalyze the conversion of homocysteine (Hcy) to methionine (Met), which helps regulate Hcy levels and Met biosynthesis [32,33]. In our study, the expression of BHMTs decreased significantly under heat stress, which would result in changes in the concentrations of many metabolites and enzymes activities involved in Met, Hcy, and one-carbon metabolism [34]. Together with the reduction in other enzymes involved with amino acid metabolism, we suggest that heat stress may disrupt amino acid homeostasis. Hence, more attention should be paid to the nutrient requirements and amino acid deficiency diseases in sea cucumbers under stress. 
In contrast, fewer proteins of carbohydrate transport and metabolism were involved under stress, as only one protein (lactase) was upregulated and two ( $\alpha$-mannosidase $2 \mathrm{C} 1$-like and pyruvate carboxylase) were downregulated. Expression of the key enzymes in the glycolytic pathway did not change, such as 6-phosphofructo-2-kinase and pyruvate kinase, indicating that short-term heat stress has no significant influence on this process [26] (Table S1). Pyruvate carboxylase, which synthesizes phosphoenolpyruvate from pyruvate during gluconeogenesis, was downregulated [35]. Thus, gluconeogenesis was likely depressed under heat stress.

\subsection{Energy Production and Usage}

Eight proteins involved in energy production and conversion were upregulated. Electron transfer flavoprotein (ETF) is located on the matrix face of the inner mitochondrial membrane and is a specific electron acceptor [36]. This protein is an important part of the electron transport chain, as it creates an electrochemical proton gradient that drives ATP synthesis. ETF was more abundantly expressed in A. japonicus under heat stress, suggesting that regulating HS demands additional energy [25]. However, the electron transport chain is the major site of ROS production, which may be the reason why high temperature increases the ROS levels in the cell $[37,38]$.

Isocitrate dehydrogenase, a critical tricarboxylic acid (TCA) cycle enzyme, catalyzes the oxidative decarboxylation of isocitrate to produce $\alpha$-ketoglutarate, using NAD+ or NADP+ as a co-factor [39]. Upregulation of isocitrate dehydrogenase accelerates the TCA cycle, suggesting an urgent need for energy. Additionally, isocitrate dehydrogenase is involved in controlling the mitochondrial redox balance and cellular defense against ROS, and overexpression of this enzyme results in protection from ROS-induced damage in mouse cells [40]. Isocitrate dehydrogenase increased in abundance in blue mussel Mytilus trossulus under heat stress while decreased in sea urchin Strongylocentrotus purpuratus exposed to stressful ultraviolet radiation [41,42]. Hence species may have different approaches to sense and deal with ROS [42].

These findings suggest that high temperature induces increase in the ROS production, which functions as a signal for activating a shift in metabolic pathways to enhance ROS-scavenging in A. japonicus.

\subsection{Transcription and Translation}

Our proteomics data show that the majority of proteins involved in transcription and translation were downregulated, including splicing factor, THO complex subunit 4 , small nuclear ribonucleoprotein-associated proteins $\mathrm{B}$ and $\mathrm{B}^{\prime}$ and $60 \mathrm{~S}$ ribosomal proteins. Global transcription and translation decrease in response to most types of cellular stress $[29,43,44]$. It is estimated that up to $50 \%$ of cellular energy, depending on the organism, is consumed in the translation process [45,46]. Hence, this decrease allows for a notable cellular energy savings. Furthermore, reducing protein synthesis avoids exposing nascent polypeptides to denaturing conditions that could further intensify the cellular stress response [44].

Only a few specific proteins participating in protein synthesis were more abundantly expressed in the HS group, such as elongation factor thermo unstable (EF-Tu). Actually, the functions of EF-Tu are not limited to a translation elongation factor but include chaperoning [47]. EF-Tu is an important HS response protein in many species, and high EF-Tu expression is correlated with thermo-tolerance [48-50].

\subsection{Cell Apoptosis and Proliferation}

Cell apoptosis signal occurs under heat stress. Apoptosis-inducing factor 1, a ubiquitous mitochondrial flavoprotein that participates in the degradation phase of apoptosis, rose 1.28-fold under heat stress in A. japonicus [51]. This result indicate that apoptosis is more predominant under heat stress, which agrees with the apoptotic signals detected in our previous ultrastructural observations, such as condensed chromatin and disappearing cytoplasm [17]. 
The evidence for decreased cell proliferation is quite clear. For example, two key antiproliferative proteins (prohibitin and autocrine proliferation repressor protein) were upregulated 1.19- and 3.57-fold, respectively [52,53]. Moreover, two types of histone proteins (histone H1 and histone H3.3) are less abundant under heat stress. Histone proteins are responsible for regulating DNA-templating processes, including DNA replication and repair [54]. Therefore, downregulation of histone proteins reflects decreased cell proliferation under stress.

\subsection{Other Processes}

Many other proteins were involved in the A. japonicus heat stress response. For example, we identified nine cytoskeletal proteins with decreased expression, suggesting the induction of apoptosis and depressed cell proliferation under heat stress $[55,56]$. Furthermore, cytoskeletal elements are composed of sarcomeres and reducing their expression decreases muscle contraction under heat stress [57,58]. The levels of hormonal and nerve regulation change under heat stress, which influence metabolism, signal transport, and other physiological functions [59-61]. Additionally, many uncharacterized proteins and proteins whose roles in the HS response remain unknown were detected. These results show the complexity of the HS response.

\section{Materials and Methods}

\subsection{Animals and Samples}

A. japonicus (mean weight, $99 \pm 13 \mathrm{~g}$ ) were supplied by a commercial farm in Qingdao (Shandong, China) in April 2015. Seawater temperature of the farm was about $13^{\circ} \mathrm{C}$. The sea cucumbers were transported to our laboratory and maintained in seawater tanks $\left(30 \%\right.$ salinity, $\left.15{ }^{\circ} \mathrm{C}\right)$ for 2 weeks. The sea cucumbers were fed with a formulated diet $(5.04 \% \pm 0.19 \%(w / w)$ crude protein, $0.26 \% \pm 0.05 \%$ $(w / w)$ fat, and $72.20 \% \pm 0.19 \%(w / w)$ ash) during the acclimation and experimental periods, and remaining feed was removed daily.

A rapid temperature-change regime was carried out in the treatment tank, using a 2-kW heating rod. The rate of heating was about $2{ }^{\circ} \mathrm{C} / \mathrm{h}$. The moment when water temperature rose to $26^{\circ} \mathrm{C}$ was regarded as the initial time, and water temperature maintained at $26^{\circ} \mathrm{C}$ in the subsequent experiment. Intestinal tissues of $A$. japonicus after a $48 \mathrm{~h}$ exposure were sampled as the heat stress (HS) group while those from an untreated tank were sampled as the control (C) group. No sea cucumbers died during the experiment. The intestinal tissues were frozen in liquid nitrogen and stored at $-80^{\circ} \mathrm{C}$.

\subsection{Protein Extraction, Digestion, and iTRAQ Labeling}

Three biological replicates of the frozen intestinal tissues were prepared for the iTRAQ analysis. The tissue was ground to powder in liquid nitrogen and dissolved in lysis buffer $(7 \mathrm{M}$ urea, $2 \mathrm{M}$ thiourea, $4 \%$ CHAPS, and $40 \mathrm{mM}$ Tris-HCl, $\mathrm{pH}$ 8.5) containing $1 \mathrm{mM}$ PMSF and $2 \mathrm{mM}$ EDTA. $10 \mathrm{mM}$ DTT was added to the lysis buffer after $5 \mathrm{~min}$. An ultrasound on ice for $15 \mathrm{~min}$ was carried out to mix the suspension, which was then centrifuged at $25,000 \times g$ for $20 \mathrm{~min}$ at $4{ }^{\circ} \mathrm{C}$. The supernatant was transferred to chilled acetone and precipitated at $-20^{\circ} \mathrm{C}$ overnight. The supernatant was discarded after centrifugation at $25,000 \times \mathrm{g}$ for $30 \mathrm{~min}$ at $4{ }^{\circ} \mathrm{C}$, and the precipitate was washed three times with chilled acetone for $30 \mathrm{~min}$ each at $4{ }^{\circ} \mathrm{C}$. The pellets were air-dried and dissolved in lysis buffer using ultrasound. The supernatant was reduced with $10 \mathrm{mM} \mathrm{DTT}$ at $56^{\circ} \mathrm{C}$ for $1 \mathrm{~h}$ after centrifugation at $25,000 \times \mathrm{g}$ for $30 \mathrm{~min}$ at $4{ }^{\circ} \mathrm{C}$ and alkylated immediately with $55 \mathrm{mM}$ iodoacetamide in the dark at room temperature for $1 \mathrm{~h}$. The treated proteins were precipitated in acetone at $-20^{\circ} \mathrm{C}$ for $3 \mathrm{~h}$. The proteins were dissolved in buffer containing $1 \mathrm{mM}$ PMSF and $2 \mathrm{mM}$ EDTA using ultrasound after centrifugation at $25,000 \times \mathrm{g}$ for $20 \mathrm{~min}$ at $4{ }^{\circ} \mathrm{C}$ and air-drying. The proteins were recovered after centrifugation at $25,000 \times \mathrm{g}$ for $20 \mathrm{~min}$ at $4{ }^{\circ} \mathrm{C}$ and quantified using the Bradford method.

The protein samples were digested with Trypsin Gold (Promega, Madison, WI, USA) at $37^{\circ} \mathrm{C}$ for $16 \mathrm{~h}$, and the peptides were dried by vacuum centrifugation. An isobaric tag was labeled to the control 
$(113,114$ and $116 \mathrm{Da})$ and HS samples $(118,119$ and $121 \mathrm{Da})$, following the manufacturer's instructions for the iTRAQ 8-plex reagents (Applied Biosystems, Foster City, CA, USA).

\subsection{Fractionation by Strong Cation Exchange Chromatography (SCX) and Liquid Chromatography-Tandem} Mass Spectrometry (LC-MS/MS) Analysis

The labeled samples were fractionated on a SCX column using the LC-20AB high performance liquid chromatography (HPLC) pump system (Shimadzu, Kyoto, Japan). The peptides were eluted with a gradient of buffer $\mathrm{A}\left(25 \mathrm{mM} \mathrm{NaH}_{2} \mathrm{PO}_{4}\right.$ in $25 \% \mathrm{ACN}$, pH 2.7) and buffer $\mathrm{B}\left(25 \mathrm{mM} \mathrm{NaH}_{2} \mathrm{PO}_{4}\right.$ and $1 \mathrm{M} \mathrm{KCl}$ in $25 \% \mathrm{ACN}, \mathrm{pH} 2.7)$. The specific fractionating procedures were as follows: $100 \%$ buffer A for the first $10 \mathrm{~min}, 5 \%-60 \%$ buffer B for $27 \mathrm{~min}, 60 \%-100 \%$ buffer B for $1 \mathrm{~min}$, and $100 \%$ buffer B for $1 \mathrm{~min}$. Absorbance of the eluate was measured at $214 \mathrm{~nm}$, and fractions were collected every min. The eluted peptides were desalted with a Strata X C18 column (Phenomenex, Torrance, CA, USA) and vacuum-dried.

A LC-20AD nanoHPLC (Shimadzu, Kyoto, Japan) and a $10 \mathrm{~cm}$ eluting C18 column were used to analyze the peptide fractions. Mass spectrometry data were acquired with the Triple TOF 5600 system (AB SCIEX, Concord, ON, Canada) fitted with the Nanospray III source (AB SCIEX) and a pulled quartz tip emitter (New Objectives, Woburn, MA, USA).

\subsection{Protein Identification and Quantification}

The raw LC-MS/MS data were converted to MGF files using Proteome Discovery 1.2 (Thermo, Pittsburgh, PA, USA). The proteins were identified using Mascot search engine 2.3.02 (Matrix Science, London, UK) with the A. japonicus transcriptomics database containing 30,622 sequences. Proteins containing at least two unique spectra were used for the follow-up quantification analysis. The quantitative protein ratios were weighted and normalized in Mascot. We only identified proteins with $p$-values $<0.05$ and fold changes $>1.20$ or $<0.83$ as being differentially expressed [62].

\subsection{GO and KEGG Pathway Enrichment Analyses}

The GO and KEGG databases were used to classify and group the identified proteins $[63,64]$. The hypergeometric test was used to identify significantly enriched GO terms and pathways of differentially expressed proteins. A $p$-value $<0.05$ was considered as significant.

\section{Conclusions}

This study provides a global view of the proteins differentially expressed in the intestinal tissues of $A$. japonicus under heat stress using the iTRAQ technique. Heat stress influences the expression of proteins involved in various biological processes, such as tissue protection and detoxification, lipid and amino acid metabolism, energy production and usage, transcription and translation, cell apoptosis, and cell proliferation. These results reveal possible molecular events in A. japonicus under heat stress.

Supplementary Materials: Supplementary materials can be found at http://www.mdpi.com/1422-0067/ $17 / 2 / 150 /$ s1.

Acknowledgments: This research was supported by the NSFC-Shandong Joint Fund for Marine Science Research Centers (U1406403), the National Natural Science Foundation of China (41406168), and Agricultural Seed Project of Shandong Province, Ecological Security and Environmental Guarantee of Marine Ranching (XDA11020703) and Chinese National 863 Project (2012AA10A412).

Author Contributions: Dongxue $\mathrm{Xu}$, Lina Sun and Hongsheng Yang conceived and supervised the study; Dongxue $\mathrm{Xu}$ and Hongsheng Yang designed the experiments; Dongxue $\mathrm{Xu}$ and Lina Sun performed the experiment and analyzed data; Dongxue Xu wrote the manuscript; Shilin Liu and Libin Zhang made manuscript revision.

Conflicts of Interest: The authors declare no conflict of interest. 


\section{References}

1. Stocker, T.F.; Qin, D.; Plattner, G.-K.; Tignor, M.; Allen, S.K.; Boschung, J.; Nauels, A.; Xia, Y.; Bex, V.; Midgley, P.M. Climate change 2013: The physical science basis. In Contribution of Working Group I to the Fifth Assessment Report of the Intergovernmental Panel on Climate Change; Cambridge University Press: Cambridge, UK, 2013.

2. Liao, Y. Fauna sinica: Phylum echinodermata. In Class Holothuroidea (in Chinese); Science Press: Beijing, China, 1997.

3. Ji, T.; Dong, Y.; Dong, S. Growth and physiological responses in the sea cucumber, Apostichopus japonicus selenka: Aestivation and temperature. Aquaculture 2008, 283, 180-187. [CrossRef]

4. Xu, D.; Sun, L.; Liu, S.; Zhang, L.; Ru, X.; Zhao, Y.; Yang, H. Molecular cloning of heat shock protein 10 (Hsp10) and 60 (Hsp60) cDNAs and their expression analysis under thermal stress in the sea cucumber Apostichopus japonicus. Comp. Biochem. Physiol. B Biochem. Mol. Biol. 2014, 171, 49-57. [CrossRef] [PubMed]

5. Zhao, H.; Yang, H.; Zhao, H.; Chen, M.; Wang, T. The molecular characterization and expression of heat shock protein 90 (Hsp90) and 26 (Hsp26) cDNAs in sea cucumber (Apostichopus japonicus). Cell Stress Chaperones 2011, 16, 481-493. [CrossRef] [PubMed]

6. Zhang, P.; Lu, Y.; Li, C.; Su, X.; Wang, Z.; Jin, C.; Li, Y.; Li, T. Identification of differential expressed proteins and characterization their mRNA expression in thermally stressed Apostichopus japonicus. Comp. Biochem. Physiol. D Genom. Proteom. 2013, 8, 194-200. [CrossRef] [PubMed]

7. Zieske, L.R. A perspective on the use of $\mathrm{iTRAQ}{ }^{\mathrm{TM}}$ reagent technology for protein complex and profiling studies. J. Exp. Bot. 2006, 57, 1501-1508. [CrossRef] [PubMed]

8. Wu, W.W.; Wang, G.; Baek, S.J.; Shen, R.-F. Comparative study of three proteomic quantitative methods, DIGE, cICAT, and iTRAQ, using 2D gel-or LC-MALDI TOF/TOF. J. Proteome Res. 2006, 5, 651-658. [CrossRef] [PubMed]

9. Karp, N.A.; Huber, W.; Sadowski, P.G.; Charles, P.D.; Hester, S.V.; Lilley, K.S. Addressing accuracy and precision issues in iTRAQ quantitation. Mol. Cell. Proteom. 2010, 9, 1885-1897. [CrossRef] [PubMed]

10. Vizcaíno, J.A.; Deutsch, E.W.; Wang, R.; Csordas, A.; Reisinger, F.; Ríos, D.; Dianes, J.A.; Sun, Z.; Farrah, T.; Bandeira, N. Proteomexchange provides globally coordinated proteomics data submission and dissemination. Nat. Biotechnol. 2014, 32, 223-226. [CrossRef] [PubMed]

11. Wang, Q.; Yu, S.; Dong, Y. Parental effect of long acclimatization on thermal tolerance of juvenile sea cucumber Apostichopus japonicus. PLoS ONE 2015, 10, e0143372. [CrossRef] [PubMed]

12. Parsell, D.; Lindquist, S. The function of heat-shock proteins in stress tolerance: Degradation and reactivation of damaged proteins. Annu. Rev. Genet. 1993, 27, 437-496. [CrossRef] [PubMed]

13. Young, J.C.; Moarefi, I.; Hartl, F.U. Hsp90: A specialized but essential protein-folding tool. J. Cell Biol. 2001, 154, 267-273. [CrossRef] [PubMed]

14. Richter, K.; Buchner, J. Hsp90: Chaperoning signal transduction. J. Cell. Physiol. 2001, 188, $281-290$. [CrossRef] [PubMed]

15. Daugaard, M.; Rohde, M.; Jäättelä, M. The heat shock protein 70 family: Highly homologous proteins with overlapping and distinct functions. FEBS Lett. 2007, 581, 3702-3710. [CrossRef] [PubMed]

16. Clerico, E.M.; Tilitsky, J.M.; Meng, W.; Gierasch, L.M. How Hsp70 molecular machines interact with their substrates to mediate diverse physiological functions. J. Mol. Biol. 2015, 427, 1575-1588. [CrossRef] [PubMed]

17. Xu, D.; Sun, L.; Liu, S.; Zhang, L.; Yang, H. Histological, ultrastructural and heat shock protein 70 (HSP70) responses to heat stress in the sea cucumber Apostichopus japonicus. Fish Shellfish Immunol. 2015, 45, 321-326. [CrossRef] [PubMed]

18. Queitsch, C.; Hong, S.-W.; Vierling, E.; Lindquist, S. Heat shock protein 101 plays a crucial role in thermotolerance in Arabidopsis. Plant Cell 2000, 12, 479-492. [CrossRef] [PubMed]

19. Mogk, A.; Kummer, E.; Bukau, B. Cooperation of Hsp70 and Hsp100 chaperone machines in protein disaggregation. Front. Mol. Biosci. 2015, 2, 22. [CrossRef] [PubMed]

20. Calderwood, S.K.; Khaleque, M.A.; Sawyer, D.B.; Ciocca, D.R. Heat shock proteins in cancer: Chaperones of tumorigenesis. Trends Biochem. Sci. 2006, 31, 164-172. [CrossRef] [PubMed]

21. Höhfeld, J.; Hartl, F.U. Role of the chaperonin cofactor Hsp10 in protein folding and sorting in yeast mitochondria. J. Cell Biol. 1994, 126, 305-315. [CrossRef] [PubMed] 
22. Maher, P. The effects of stress and aging on glutathione metabolism. Ageing Res. Rev. 2005, 4, $288-314$. [CrossRef] [PubMed]

23. Dickinson, D.A.; Forman, H.J. Glutathione in defense and signaling: Lessons from a small thiol. Ann. N. Y. Acad. Sci. 2002, 973, 488-504. [CrossRef] [PubMed]

24. Eaton, D.L.; Bammler, T.K. Concise review of the glutathione $S$-transferases and their significance to toxicology. Toxicol. Sci. 1999, 49, 156-164. [CrossRef] [PubMed]

25. Wei, D.; Jia, F.-X.; Tian, C.-B.; Tian, Y.; Smagghe, G.; Dou, W.; Wang, J.-J. Comparative proteomic analysis of Bactrocera dorsalis (Hendel) in response to thermal stress. J. Insect Physiol. 2015, 74, 16-24. [CrossRef] [PubMed]

26. Liu, G.-T.; Ma, L.; Duan, W.; Wang, B.-C.; Li, J.-H.; Xu, H.-G.; Yan, X.-Q.; Yan, B.-F.; Li, S.-H.; Wang, L.-J. Differential proteomic analysis of grapevine leaves by iTRAQ reveals responses to heat stress and subsequent recovery. BMC Plant Biol. 2014, 14, 110-126. [CrossRef] [PubMed]

27. Thorpe, C.; Kim, J.J.P. Flavoprotein structure and mechanism of action of the acyl-coa dehydrogenases. FASEB J. 1995, 9, 718-725. [PubMed]

28. Bahnson, B.J.; Anderson, V.E.; Petsko, G.A. Structural mechanism of enoyl-CoA hydratase: Three atoms from a single water are added in either an E1cb stepwise or concerted fashion. Biochemistry 2002, 41, 2621-2629. [CrossRef] [PubMed]

29. Heunis, T.; Deane, S.; Smit, S.; Dicks, L.M. Proteomic profiling of the acid stress response in Lactobacillus plantarum 423. J. Proteome Res. 2014, 13, 4028-4039. [CrossRef] [PubMed]

30. Thorne, M.A.S.; Burns, G.; Fraser, K.P.P.; Hillyard, G.; Clark, M.S. Transcription profiling of acute temperature stress in the Antarctic plunderfish Harpagifer antarcticus. Mar. Genom. 2010, 3, 35-44. [CrossRef] [PubMed]

31. Sun, J.; Mu, H.; Zhang, H.; Chandramouli, K.H.; Qian, P.-Y.; Wong, C.K.C.; Qiu, J.-W. Understanding the regulation of estivation in a freshwater snail through iTRAQ-based comparative proteomics. J. Proteome Res. 2013, 12, 5271-5280. [CrossRef] [PubMed]

32. Skiba, W.E.; Taylor, M.; Wells, M.; Mangum, J.H.; Awad, W. Human hepatic methionine biosynthesis. Purification and characterization of betaine homocysteine S-methyltransferase. J. Biol. Chem. 1982, 257, 14944-14948. [PubMed]

33. Pajares, M.A.; Pérez-Sala, D. Betaine homocysteine $S$-methyltransferase: Just a regulator of homocysteine metabolism? Cell. Mol. Life Sci. 2006, 63, 2792-2803. [CrossRef] [PubMed]

34. Teng, Y.-W.; Mehedint, M.G.; Garrow, T.A.; Zeisel, S.H. Deletion of betaine-homocysteine S-methyltransferase in mice perturbs choline and L-carbon metabolism, resulting in fatty liver and hepatocellular carcinomas. J. Biol. Chem. 2011, 286, 36258-36267. [CrossRef] [PubMed]

35. Bahl, J.J.; Matsuda, M.; DeFronzo, R.A.; Bressler, R. In vitro and in vivo suppression of gluconeogenesis by inhibition of pyruvate carboxylase. Biochem. Pharmacol. 1997, 53, 67-74. [CrossRef]

36. Weidenhaupt, M.; Rossi, P.; Beck, C.; Fischer, H.M.; Hennecke, H. Bradyrhizobium japonicum possesses two discrete sets of electron transfer flavoprotein genes: fixA, fixB and etfS, etfL. Arch. Microbiol. 1996, 165, 169-178. [CrossRef] [PubMed]

37. Hasanuzzaman, M.; Nahar, K.; Alam, M.M.; Roychowdhury, R.; Fujita, M. Physiological, biochemical, and molecular mechanisms of heat stress tolerance in plants. Int. J. Mol. Sci. 2013, 14, 9643-9684. [CrossRef] [PubMed]

38. Tomanek, L. Proteomics to study adaptations in marine organisms to environmental stress. J. Proteom. 2014, 105, 92-106. [CrossRef] [PubMed]

39. Alp, P.R.; Newsholme, E.A.; Zammit, V.A. Activities of citrate synthase and NAD ${ }^{+}$-linked and NADP ${ }^{+}$-linked isocitrate dehydrogenase in muscle from vertebrates and invertebrates. Biochem. J. 1976, 154, 689-700. [CrossRef] [PubMed]

40. Jo, S.-H.; Son, M.-K.; Koh, H.-J.; Lee, S.-M.; Song, I.-H.; Kim, Y.-O.; Lee, Y.-S.; Jeong, K.-S.; Kim, W.B.; Park, J.-W. Control of mitochondrial redox balance and cellular defense against oxidative damage by mitochondrial $\mathrm{NADP}^{+}$-dependent isocitrate dehydrogenase. J. Biol. Chem. 2001, 276, 16168-16176. [CrossRef] [PubMed]

41. Fields, P.A.; Zuzow, M.J.; Tomanek, L. Proteomic responses of blue mussel (Mytilus) congeners to temperature acclimation. J. Exp. Biol. 2012, 215, 1106-1116. [CrossRef] [PubMed]

42. Adams, N.; Campanale, J.; Foltz, K. Proteomic responses of sea urchin embryos to stressful ultraviolet radiation. Integr. Comp. Biol. 2012, 52, 665-680. [CrossRef] [PubMed] 
43. Ji, C.; Wu, H.; Wei, L.; Zhao, J. ITRAQ-based quantitative proteomic analyses on the gender-specific responses in mussel Mytilus galloprovincialis to tetrabromobisphenol A. Aquat. Toxicol. 2014, 157, 30-40. [CrossRef] [PubMed]

44. Holcik, M.; Sonenberg, N. Translational control in stress and apoptosis. Nat. Rev. Mol. Cell Biol. 2005, 6, 318-327. [CrossRef] [PubMed]

45. Warner, J.R. The economics of ribosome biosynthesis in yeast. Trends Biochem. Sci. 1999, 24, 437-440. [CrossRef]

46. Rudra, D.; Warner, J.R. What better measure than ribosome synthesis? Genes Dev. 2004, 18, $2431-2436$. [CrossRef] [PubMed]

47. Suzuki, H.; Ueda, T.; Taguchi, H.; Takeuchi, N. Chaperone properties of mammalian mitochondrial translation elongation factor Tu. J. Biol. Chem. 2007, 282, 4076-4084. [CrossRef] [PubMed]

48. Bhadula, S.K.; Elthon, T.E.; Habben, J.E.; Helentjaris, T.G.; Jiao, S.; Ristic, Z. Heat-stress induced synthesis of chloroplast protein synthesis elongation factor (EF-Tu) in a heat-tolerant maize line. Planta 2001, 212, 359-366. [CrossRef] [PubMed]

49. Ristic, Z.; Wilson, K.; Nelsen, C.; Momcilovic, I.; Kobayashi, S.; Meeley, R.; Muszynski, M.; Habben, J. A maize mutant with decreased capacity to accumulate chloroplast protein synthesis elongation factor (EF-Tu) displays reduced tolerance to heat stress. Plant Sci. 2004, 167, 1367-1374. [CrossRef]

50. Buckley, B.A.; Gracey, A.Y.; Somero, G.N. The cellular response to heat stress in the goby Gillichthys mirabilis: A cDNA microarray and protein-level analysis. J. Exp. Biol. 2006, 209, 2660-2677. [CrossRef] [PubMed]

51. Susin, S.A.; Lorenzo, H.K.; Zamzami, N.; Marzo, I.; Snow, B.E.; Brothers, G.M.; Mangion, J.; Jacotot, E.; Costantini, P.; Loeffler, M. Molecular characterization of mitochondrial apoptosis-inducing factor. Nature 1999, 397, 441-446. [PubMed]

52. Ikonen, E.; Fiedler, K.; Parton, R.G.; Simons, K. Prohibitin, an antiproliferative protein, is localized to mitochondria. FEBS Lett. 1995, 358, 273-277. [CrossRef]

53. Brock, D.A.; Gomer, R.H. A secreted factor represses cell proliferation in dictyostelium. Development 2005, 132, 4553-4562. [CrossRef] [PubMed]

54. Strahl, B.D.; Allis, C.D. The language of covalent histone modifications. Nature 2000, 403, 41-45. [CrossRef] [PubMed]

55. Marushige, Y.; Marushige, K. Alterations in focal adhesion and cytoskeletal proteins during apoptosis. Anticancer Res. 1997, 18, 301-307.

56. Cordeiro, O.D.; Silva, T.S.; Alves, R.N.; Costas, B.; Wulff, T.; Richard, N.; de Vareilles, M.; Conceição, L.E.; Rodrigues, P.M. Changes in liver proteome expression of senegalese sole (Solea senegalensis) in response to repeated handling stress. Mar. Biotechnol. 2012, 14, 714-729. [CrossRef] [PubMed]

57. Gunst, S.J.; Zhang, W. Actin cytoskeletal dynamics in smooth muscle: A new paradigm for the regulation of smooth muscle contraction. Am. J. Physiol. Cell Physiol. 2008, 295, C576-C587. [CrossRef] [PubMed]

58. Campbell, K.P. Three muscular dystrophies: Loss of cytoskeleton-extracellular matrix linkage. Cell 1995, 80, 675-679. [CrossRef]

59. Soffer, R.L. Angiotensin-converting enzyme and the regulation of vasoactive peptides. Annu. Rev. Biochem. 1976, 45, 73-94. [CrossRef] [PubMed]

60. Dingledine, R.; Borges, K.; Bowie, D.; Traynelis, S.F. The glutamate receptor ion channels. Pharmacol. Rev. 1999, 51, 7-62. [PubMed]

61. Miller, C. An overview of the potassium channel family. Genome Biol. 2000, 1, 1-5. [CrossRef] [PubMed]

62. Briolant, S.; Almeras, L.; Belghazi, M.; Boucomont-Chapeaublanc, E.; Wurtz, N.; Fontaine, A.; Granjeaud, S.; Fusaï, T.; Rogier, C.; Pradines, B. Research Plasmodium falciparum proteome changes in response to doxycycline treatment. Malar. J. 2010, 9, 141-154. [CrossRef] [PubMed]

63. Gene Ontology Consortium. Available online: http://www.geneontology.org/ (accessed on 20 May 2015).

64. KEGG: Kyoto Encyclopedia of Genes and Genomes. Available online: http://www.genome.jp/kegg/ (accessed on 20 May 2015).

(C) 2016 by the authors; licensee MDPI, Basel, Switzerland. This article is an open access article distributed under the terms and conditions of the Creative Commons by Attribution (CC-BY) license (http://creativecommons.org/licenses/by/4.0/). 